\title{
Prognosis of frail hospitalized COVID-19 patient: Better than expected?
}

\author{
Martial Coutaz*, Julien Lagrandeur, Botturi Cecilia and \\ Cohen Corinne
}

Geriatrics Department, University of Geneva, Hôpital du Valais, Martigny, Switzerland

Received: 22 May, 2020

Accepted: 04 June, 2020

Published: 05 June, 2020

*Corresponding author: Martial Coutaz, Geriatrics Department, University of Geneva, Hôpital du Valais, Martigny, Switzerland, Tel: 02760390 00; 02760396 37; Fax 02760396 07; E-mail:martial.coutaz@hopitalvs.ch ORCID: https://orcid.org/0000-0001-6775-6820

Keywords: COVID-19; SARS-CoV-2; Geriatric; Hospitalized; Frailty; Outcome

https://www.peertechz.com

\begin{abstract}
Objective: To evaluate the characteristics and prognosis of hospitalized geriatric COVID-19-positive patients during the first 30 days of the Swiss confinement period.

Design: A retrospective case series analyzing the characteristics and disease evolution for 81 patients admitted to the geriatric COVID-19-positive ward during a 30-day period from March 24 to April 22, 2020.
\end{abstract}

Setting and participants: Any COVID-19-positive patients who was admitted to one of four geriatric hospital sites who were $>65$ years old and did not desire intubation.

Methods: Data collection on patients admitted throughout the study period, as well as chart review for those discharged within the 30-day period to ensure that information was complete.

Results: We found a $61.5 \%$ survival rate among those in a unit with an average age of 84.4 -years and a vulnerable to frail health status, among whom $62 \%$ were male. The clinical presentation of COVID-19 in this population was similar to that described among younger populations, including a predominance of respiratory symptoms, along with fever, myalgia, asthenia, and neurologic symptoms such as anosmia and ageusia, as well as bilateral pulmonary infiltrates on chest x-ray. Poor prognosis was strongly associated with higher oxygen demands, as well as higher fever and higher CRP and procalcitonin levels.

Conclusions: In spite of an average age of 84 years and a vulnerable to frail health status, the majority of patients in this geriatric CoVID-19 ward survived to discharge. Regardless of frailty and underlying comorbidities, those who never developed severe oxygen demands were much more likely to survive. This study suggests that, among a vulnerable to frail geriatric patient cohort, the cumulative presence of inherent risk factors did not dictate prognosis. Future studies will allow us to elaborate which elements influence patients' oxygen demands, thereby permitting earlier interventions and improved prognosis.

\section{Introduction}

Severe acute respiratory syndrome coronavirus 2 (SARSCoV-2) is a single-stranded RNA virus that is responsible for the novel coronavirus disease (COVID-19), a lower respiratory tract infection that can lead to severe and even fatal disease. Transmission is thought to be primarily via respiratory droplets, although other mechanisms are still being investigated [1]. COVID-19 has affected close to 6.2 million people worldwide [2], with a variety of presenting symptoms that include fever, cough, dyspnea, myalgia, headache, sore throat, diarrhea and vomiting, along with sudden gustatory and olfactory dysfunctions [3].

Populations at increased risk of severe disease include older adults and those with serious chronic medical conditions such as cardiovascular disease, diabetes, cancer, chronic obstructive pulmonary disease, obesity and hypertension. Among those with clinical symptoms consistent with COVID-19, diagnosis is confirmed primarily from a RT-PCR on a nasopharyngeal swab. Laboratory results consistent with COVID-19 include leucocyte counts that are either above or below the normal range, along with decreased lymphocytes. C-reactive protein (CRP) is frequently elevated, and those with severe illness can present with serologic markers of hepatic and renal injury. While procalcitonin levels are generally within normal range during infection purely due to SARS-CoV-2, elevated levels often imply bacterial co-infection. Radiologic findings are variable, but among those with severe illness, bilateral and multi-lobe opacities are common, with bilateral diffuse ground glass opacities frequently found on pulmonary tomography (CT) [3]. Disease severity ranges from mild and uncomplicated, to severe with respiratory failure that can lead to death. 
Current treatments are largely supportive, including oxygen therapy, non-invasive and invasive mechanical ventilation, fluids, antivirals such as lopinavir-ritonavir and remdesivir, or antimalarial as chloroquine, and broad-spectrum antibiotics when there is evidence of secondary bacterial infection [4].

As of April 22, 2020 in Switzerland, 28,268 individuals have tested positive for SARS-CoV-2 (with a cumulative incidence of 329 per 100,000 inhabitants), among whom 1,207 have died [5]. In Valais, one of the 26 Swiss states and home to 345,000 inhabitants, 1,729 cases have been detected (cumulative incidence of 517 per 100,000 inhabitants), including 114 deaths (54 hospitalized, 60 non-hospitalized) [6].

At the beginning of the confinement period that the Swiss Federal Council issued on March 16, 2020, we opened a COVID-19 unit in the Valais Hospital (900 beds), within the geriatric department (210 beds), where we hospitalized elderly patients who did not desire intensive resuscitation (intubation and reanimation). Geriatric patients who desired intensive resuscitation were instead admitted to the internal medicine or intensive care wards.

Patients' decisions not to pursue resuscitation were made of their own free will, based on advance directives when available, as well as formal discussions at the time of admission with the patient, his family, and/or his therapeutic representative(s). As per our hospital's standards, in the setting of the ongoing pandemic, no prior explicit consent for participation in COVID19-related studies was required, as long as patients' identifying characteristics were not used.

We followed our hospital's guidelines for diagnosis and treatment, as defined collaboratively by our infectious disease experts and intensive care physicians, and adapted specifically to this geriatric do-not-resuscitate population by the Chairman of the Geriatric Department. Diagnosis was confirmed by PCR on nasopharyngeal swabs. When confronted with negative results but high clinical suspicion, up to two addition swabs and a thoracic CT scan were performed before infection was definitively ruled out. Admission tests included complete blood count with differential, chemistry panel with liver function tests, CRP and procalcitonin. A chest $\mathrm{x}$-ray was also obtained at time of admission. CT scans were obtained when (1) the chest $\mathrm{x}$-ray was normal but laboratory values pointed towards secondary bacterial infection, such as procalcitonin $>0.25 \mu \mathrm{g} / \mathrm{L}$, or (2) significant deterioration in respiratory status, as long as the patient's clinical status was stable enough to allow transfer to the radiology unit. If a purely palliative approach was in place, additional imaging was often forgone. The recommended treatment protocol was modified several times during the onemonth period, based on available studies at the time. Antibiotics were administered primarily when procalcitonin was elevated or when imaging suggested a bacterial superinfection (Meropenem 1g every 8 hours was recommended until April 1 , at which point the protocol changed to Co-amoxicillin $1.2 \mathrm{~g}$ every 8 hours for 10 days, with Azithromycin 500mg once daily for 5 days, used at individual physicians' discretion). We did not categorically provide antimalarial or antivirals, but the geriatricians were encouraged decide whether the potential benefits of chloroquine, remdesivir and lopinavir-ritonavir outweighed risks for their individual patients. In practice, we rarely initiated antiviral treatment in our patients, but at times continued antiviral treatments had been started in another service.

This study represents a novel perspective, offering insight on the impact of COVID-19 illness on this unique cohort of hospitalized patients over 65 years old who did not desire resuscitation.

\section{Clinical characteristics}

In this retrospective case series, we present relevant clinical characteristics of the 81 patients who were admitted to the geriatric COVID-19 ward during the 30-day period from March 24 to April 22, 2020, specifically focusing on the 65 who left the unit (hospital discharge or death). Seventy-nine of the patients lived at home at time of admission, and two were nursing home residents. Patients were admitted to our unit directly from home (per a family physician's request), from the emergency room, or transferred from other units (internal medicine or step-down units).

Sixty-five patients had left the geriatric COVID-19 unit by the end of the 30 days, including $25(38.4 \%)$ who died. Among the 40 survivors, 26 patients $(65 \%)$ returned directly to their home, while 14 patients $(35 \%)$ were transferred to a multidisciplinary geriatric rehabilitation unit. The average hospital stay duration was 12.9 days.

Among the 65 discharged patients, average age was 84.5 years, and $62 \%$ were male. At time of admission, $78 \%$ presented with respiratory symptoms (cough, dyspnea, pharyngitis), $71 \%$ had a temperature greater than $38^{\circ} \mathrm{C}$, and $89 \%$ had severe asthenia and/or myalgia. In addition, $60 \%$ presented with bilateral pulmonary infiltrates on chest $\mathrm{x}$-ray.

Our patients presented with an array of comorbidities: $83 \%$ with hypertension, $62 \%$ with cardiovascular disease (cardiac or peripheral artery disease), $20 \%$ with diabetes, $17 \%$ with chronic lung disease, and $14 \%$ with obesity.

We used the American Diabetes Association's (ADA) geriatric assessment scale to categorize our patients' health status based on age, cognitive status, comorbidities, functional status and life expectancy. Our patients fell into 2 of the 3 categories: none were considered fit (healthy/robust), 69\% were considered vulnerable (complex/intermediate health), and $31 \%$ were considered frail (very complex/poor health) [7] Table 1.

We were encouraged that $61.5 \%$ of our COVID-19-positive patients survived to discharge, in spite of their average age of 84.4 years and their vulnerable or frail health status.

A slight majority of the deceased patients (56\%) were considered frail. Compared to patients who survived to discharge, a higher percentage of the deceased experienced respiratory symptoms ( $96 \%$ vs $67.5 \%$ ). They also presented with more severe respiratory impairment, and lower average 
Table 1: Distribution by Survival.

\begin{tabular}{|c|c|c|c|}
\hline & All patients discharged & Alive & Died \\
\hline No. of patients (\%) & $65(100)$ & $40(61.5)$ & $25(38.5)$ \\
\hline \multicolumn{4}{|l|}{ Characteristic } \\
\hline Age, median (IQR) - y & $85(79-91)$ & $85(80-90)$ & $86(78-94)$ \\
\hline Male - no. (\%) & $40(62)$ & $20(50)$ & $20(50)$ \\
\hline \multicolumn{4}{|l|}{ Health status } \\
\hline "Very complex" patients - no. (\%) & $20(30.8)$ & $6(15)$ & $14(56)$ \\
\hline "Complex" patients - no. (\%) & $45(69.2)$ & $34(85)$ & $11(44)$ \\
\hline \multicolumn{4}{|l|}{ Common symptoms } \\
\hline $\begin{array}{l}\text { Respiratory (cough, dyspnea, } \\
\text { pharyngitis) - no. (\%) }\end{array}$ & $51(78.5)$ & $27(67.5)$ & $24(96)$ \\
\hline Fever $\geq 38^{\circ} \mathrm{C}-$ no. $(\%)$ & 46 (70.7) & $23(57.5)$ & $23(92)$ \\
\hline Asthenia, myalgia - no. (\%) & $58(89.2)$ & $34(85)$ & $24(96)$ \\
\hline $\begin{array}{l}\text { Duration of symptoms before } \\
\text { hospitalization - no. }\end{array}$ & 4,7 & 5,2 & 3,6 \\
\hline $\begin{array}{l}\text { Length of stay in the COVID-19 } \\
\text { unit - no. }\end{array}$ & 12,9 & 14,1 & 10,8 \\
\hline \multicolumn{4}{|l|}{ Comorbidities - no. (\%) } \\
\hline Hypertension & $54(83.1)$ & $33(82.5)$ & $21(84)$ \\
\hline Diabetes & $13(20)$ & $8(20)$ & $5(20)$ \\
\hline $\begin{array}{l}\text { Cardiovascular disease (cardiac, } \\
\text { peripheral artery disease) }\end{array}$ & $40(61.5)$ & $23(57.5)$ & $17(68)$ \\
\hline Chronic lung disease & $11(16.9)$ & $8(20)$ & $3(12)$ \\
\hline Obesity & $9(13.8)$ & $6(15)$ & $3(12)$ \\
\hline Cognitive disorders $(M M S<25 / 30)$ & $27(41.5)$ & $13(32.5)$ & $14(56)$ \\
\hline $\begin{array}{l}\text { Weight loss during hospitalization } \\
\qquad>3-5 \%)\end{array}$ & $25(38.5)$ & $19(47.5)$ & $6(24)$ \\
\hline \multicolumn{4}{|l|}{ Laboratory study a } \\
\hline CRP , mg/L $(<5)$ & 119,2 & 96,9 & 156 \\
\hline $\mathrm{PCT}, \mu \mathrm{g} / \mathrm{L}(<0.1 \mu \mathrm{g} / \mathrm{L})$ & 0,19 & 0,13 & 0,29 \\
\hline \multicolumn{4}{|l|}{ Chest imaging, infiltrate ${ }^{b}$} \\
\hline Bilateral - no. (\%) & $39(60)$ & $20(50)$ & $19(76)$ \\
\hline \multicolumn{4}{|l|}{ Treatment in hospital } \\
\hline Antibiotic therapy - no. (\%) & $40(61.5)$ & $20(50)$ & $20(80)$ \\
\hline Antiviral therapy - no. (\%) & $4(6.1)$ & $3(7.5)$ & $1(4)$ \\
\hline Minimum of $\mathrm{SpO} 2$ in ambient air & $84,7 \%$ & $88,6 \%$ & $78,4 \%$ \\
\hline $\begin{array}{l}\text { Oxygen therapy with mask (6L } \\
\text { d'02/FiO2 50\%) - no. (\%) }\end{array}$ & $20(30.8)$ & $2(5)$ & $18(72)$ \\
\hline $\begin{array}{c}\text { Duration (days) of oxygen therapy } \\
\text { - no. }\end{array}$ & 5,5 & 3,3 & 9 \\
\hline
\end{tabular}

${ }^{a}$ Abbreviations: CRP, high-sensitivity C-reactive protein. PCT, procalcitonin.

${ }^{\mathrm{b}}$ Including chest $\mathrm{x}$-ray and computed tomography scan.

oxygen saturation on room air (average 02 saturation of $78.4 \%$ for those who died, vs $88.6 \%$ for those who survived to discharge). Additionally, we found that they had more intense oxygen demands $(72 \%$ of those who died required $6 \mathrm{~L}$ of $50 \%$ FiO2, vs $5 \%$ of survivors) and required supplemental oxygen for a longer time period ( 9 vs 3.3 days).

Finally, the deceased were more likely to have a fever > $38^{\circ} \mathrm{C}(92 \%$ vs $57.5 \%)$ and bilateral infiltrates on $\mathrm{x}$-ray $(76 \%$ vs $50 \%$ ), plus had higher mean CRP values ( $156 \mathrm{mg} / \mathrm{L}$ vs 96.9 $\mathrm{mg} / \mathrm{L})$ and procalcitonin values $(0.28 \mu \mathrm{g} / \mathrm{L}$ vs $0.13 \mu \mathrm{g} / \mathrm{L})$, along with elevated LDH and lymphopenia (<1g/L).
Table 2 describes surviving patients' characteristics, distinguishing between those who were discharged to home (65\%) and those who transferred to a geriatric rehabilitation unit. Patients who discharged to home were slightly younger (median age 85 vs 86 years), less frail, slightly less likely to suffer from cognitive impairment (30.8 vs $35.7 \%$ ), and less likely to have experienced significant ( $>5 \%$ ) weight loss during their hospitalization ( 42.3 vs $57.1 \%$ ). Interestingly, those who were discharged to home were more likely to have received antibiotic therapy ( 53.8 vs $42.9 \%$ ) and concomitant antiviral therapy (11.5 vs $0 \%)$.

\begin{tabular}{|c|c|c|c|}
\hline & $\begin{array}{l}\text { All patients } \\
\text { surviving }\end{array}$ & Back home & $\begin{array}{c}\text { Geriatric } \\
\text { rehabilitation }\end{array}$ \\
\hline No. of patients (\%) & $40(100)$ & $26(65)$ & $14(35)$ \\
\hline \multicolumn{4}{|l|}{ Characteristic } \\
\hline Age, median (IQR) - y & $85(80-90)$ & $85(79-91)$ & $86(81-91)$ \\
\hline Male - no. (\%) & $20(50)$ & $17(65.4)$ & $3(21.4)$ \\
\hline \multicolumn{4}{|l|}{ Health status } \\
\hline "Very complex" patients - no. (\%) & $6(15)$ & $3(11.5)$ & $3(21.4)$ \\
\hline "Complex" patients - no. (\%) & $34(85)$ & $24(92.3)$ & $10(71.4)$ \\
\hline \multicolumn{4}{|l|}{ Common symptoms } \\
\hline $\begin{array}{l}\text { Respiratory (cough, dyspnea, pharyngitis) } \\
- \text { no. (\%) }\end{array}$ & $27(67.5)$ & $20(76.9)$ & $7(50)$ \\
\hline Fever $\geq 38^{\circ} \mathrm{C}-$ no. $(\%)$ & $23(57.5)$ & $17(65.4)$ & $6(42.9)$ \\
\hline Asthenia, myalgia - no. (\%) & $33(82.5)$ & $22(84.6)$ & $11(78.6)$ \\
\hline $\begin{array}{l}\text { Duration of symptoms before } \\
\text { hospitalization - no. }\end{array}$ & 4,7 & 5,9 & 3,9 \\
\hline Length of stay in the COVID-19 unit - no. & 12,9 & 14,4 & 13,6 \\
\hline \multicolumn{4}{|l|}{ Comorbidities - no. (\%) } \\
\hline Hypertension & $35(87.5)$ & $24(92.3)$ & $9(64.3)$ \\
\hline Diabetes & $8(20)$ & $6(23.1)$ & $2(14.3)$ \\
\hline $\begin{array}{l}\text { Cardiovascular disease (cardiac, } \\
\text { peripheral artery disease) }\end{array}$ & $23(57.5)$ & $18(69.2)$ & $5(35.7)$ \\
\hline Chronic lung disease & $8(20)$ & $6(23.1)$ & $2(14.3)$ \\
\hline Obesity & $6(15)$ & $4(15.4)$ & $2(14.3)$ \\
\hline Cognitive disorders $(M M S<25 / 30)$ & $13(32.5)$ & $8(30.8)$ & $5(35.7)$ \\
\hline Weight loss during hospitalization (>3-5\%) & $19(47.5)$ & $11(42.3)$ & $8(57.1)$ \\
\hline \multicolumn{4}{|l|}{ Laboratory study a } \\
\hline CRP , mg/L $(<5)$ & 96,9 & 96,3 & 96,0 \\
\hline PCT,$\mu \mathrm{g} / \mathrm{L}(<0.1 \mu \mathrm{g} / \mathrm{L})$ & 0,13 & 0,14 & 0,11 \\
\hline \multicolumn{4}{|l|}{ Chest imaging, infiltrate ${ }^{b}$} \\
\hline Bilateral - no. (\%) & $20(50)$ & $14(53.8)$ & $6(42.9)$ \\
\hline \multicolumn{4}{|l|}{ Treatment in hospital } \\
\hline Antibiotic therapy - no. (\%) & $20(50)$ & $14(53.8)$ & $6(42.9)$ \\
\hline Antiviral therapy - no. (\%) & $3(7.5)$ & $3(11.5)$ & 0 \\
\hline Minimum of SpO2 in ambient air & $88,6 \%$ & $89,1 \%$ & $89,1 \%$ \\
\hline $\begin{array}{l}\text { Oxygen therapy with mask (6L d'02/FiO2 } \\
50 \% \text { - no. (\%) }\end{array}$ & $2(5)$ & $2(5)$ & 0 \\
\hline Duration (days) of oxygen therapy no. & 3,3 & 3,4 & 3,1 \\
\hline
\end{tabular}

\begin{tabular}{|l|l|l|l|}
\hline Duration (days) of oxygen therapy no. & 3,3 & 3,4 & 3,1
\end{tabular}

a Abbreviations: CRP, high-sensitivity C-reactive protein. PCT, procalcitonin. ${ }^{b}$ Including chest $\mathrm{x}$-ray and computed tomography scan 


\section{Reflections on caring for geriatric COVID-19-positive patients}

- Overall, the patients hospitalized in our geriatric COVID-19 ward were an average age of 84.5 years, with a vulnerable to frail health status. At 30 days, there was a $61.6 \%$ survival rate, and $40 \%$ of the survivors were able to return directly to their homes.

- The clinical presentation of COVID-19 in this elderly vulnerable population was similar to that described in younger populations: slight predominance of male gender, presenting primarily with respiratory symptoms and fever, as well as bilateral infiltrates on chest $\mathrm{x}$-ray [8-16].

- Many of our patients developed neurological symptoms, such as loss of taste and smell (anosmia / ageusia) - which exacerbates an already severe lack of appetite - and significant asthenia, psychomotor retardation, and temporospatial disorientation, corresponding to hypoactive delirium. We observed clinical signs of encephalitis in only two patients, but no signs of clinical seizures among our patients, nor ischemic or hemorrhagic lesions on brain imaging.

- Despite several risk factors (fever, dehydration, decreased mobility, significant inflammation), we did not identify thromboembolic complications in any of our patients (negative chest CT angiography, performed if clinical suspicion), a complication which has been described frequently among COVID-19-positive patients elsewhere in the literature.

- Poor prognosis was more strongly associated with high oxygen requirement, than with age or number of comorbidities. Those who did not survive to discharge were more likely to have presented with rapidly increasing oxygen demands. Despite high flow oxygen (Venturi mask at 6L with 50\% FiO2), almost none survived this period. However, those who did not experience massive respiratory demands during the first critical 10-day period were much more likely to survive. Many of the survivors experienced a fairly sudden improvement in their general condition at some point after day 10, with a boost of energy and a renewed appetite.

- Supporting dying patients was extremely difficult due to the physical absence of loved ones. Our hospital COVID-19 policy prohibited any patient visits, with an exception made only for those in terminal condition. Dying patients were allowed one 10-minute visit per day from a single family member. Although our hospital provided an electronic tablet for each unit in order to enhance communication with families, these were often difficult to use due to our patients' impaired vision and hearing, confusion, and altered mental status. The inability to provide family-supported end-of-life care served as a significant source of psychological stress for patients, families, and the medical care team.

\section{Comment}

This case series suggests that, among a vulnerable geriatric patient cohort, the cumulative presence of inherent risk factors did not seem a reliable predictor of prognosis. It remains unclear which risk factors and clinical characteristics dictate that a patient will be more likely to develop acute respiratory decompensation, thereby predicting higher mortality. The theory that thromboembolic events explain this decline was not corroborated within our population, even though our patients were admittedly less likely to receive repeat CT-scans than those in more intensive care settings. Additionally, our data was limited by the fact that we were frequently providing palliative care, and thereby choose to forgo exhaustive investigations unless the results were expected to significantly alter treatment. Due to the observational nature of this small study, we were unable to perform a statistic analysis that would allow us to draw conclusions on which risk factors and therapies had the greatest influence on outcome. Future studies will allow further clarification of the associations that we observed on our unit. We hope that future studies will also help better identify the elements that determine which patients experience high oxygen demands, thereby permitting earlier interventions and improved outcomes. Additionally, further explorations of methods for providing geriatric palliative care within the confines of a pandemic will improve the emotional and psychologic support we can offer our patients, their families and our medical teams.

\section{References}

1. Coronavirus Disease 2019 (COVID-19) (2020) Prevention and Treatment Centers for Disease Control and Prevention. Link: https://bit.ly/3glOlnw

2. Johns Hopkins COVID-19 Dashbord by the Center for Systems Science and Engineering. Link: https://bit.ly/2XsE9Gn

3. Guan W, Ni ZY, Hu Y, Liang WH, Ou CQ, et al. (2020) Clinical Characteristics of Coronavirus Disease 2019 in China. N Engl J Med 382: 1708-1720. Link: https://bit.ly/2Mo8dMW

4. Sanders J, Monogue ML, Jodlowski TZ, Cutrell JB (2020) Pharmacologic Treatments for Coronavirus Disease 2019 (COVID-19). JAMA. Link: https://bit.ly/3dvGmGy

5. Infections confirmées au coronavirus, décès, situation épidémiologique. Link: https://bit.ly/2XtgBRO

6. Situation épidémiologique Valais - Epidemiologische Situation Wallis. Link: https://bit.ly/3dw6gtT

7. American Diabetes Association (2020) 12. Older Adults: Standards of Medical Care in Diabetes-2020. Diabetes Care 43: S152-S162. Link: https://bit.ly/36U4zE2

8. Goyal P, Choi JJ, Pinheiro LC, Schenck EJ, Chen R, et al. (2020) Clinical Characteristics of COVID-19 in New York City. N Engl J Med NEJMc2010419. Link: https://bit.ly/2U3C55A

9. Del Rio C, Malani PN (2020) COVID-19-New insights on a rapidly changing epidemic. JAMA 323: 1399-1340. Link: https://bit.ly/2U6C3tQ

10. Arentz M, Yim E, Klaff L, Lokhandwala S, Riedo RX, et al. (2020) Characteristics and outcomes of 21 critically ill patients with COVID-19 in Washington State. JAMA 323: 1612-1614. Link: https://bit.ly/3eXnbWP

11. Grasselli G, Zangrillo A, Zanella A (2020) Baseline characteristics and outcomes of 1591 patients infected with SARS-CoV-2 admitted to ICUs of the Lombardy region, Italy. 323: 1574-1581. Link: https://bit.ly/3eRi8Hn

12. Wang D, Hu B, Hu C (2020) Clinical characteristics of 138 hospitalized patients with 2019 novel Coronavirus-infected pneumonia in Wuhan, China. JAMA 323: 1061-1069. Link: https://bit.ly/36Yeokg 
13. Boccia S, Ricciardi W, loannidis JPA (2020) What other countries can learn from Italy during the COVID-19 Pandemic. JAMA. Link: https://bit.ly/2Xs0SSS

14. Shahid Z, Klayanamitra R, McClafferty B, et al. (2020) COVID-19 and older adults: what we know. J Am Geriatr Soc 68: 926-929. Link: https://bit.ly/2MvgNJP
15. Cesari M, Proietti M (2020) COVID-19 in Italy: ageism and decison making in a pandemic. J Am Med Dir Assoc 21: 576-577. Link: https://bit.ly/3eG2EFK

16. Parodi SM, Liu VX (2020) From Containment to mitigation of COVID-19 in the US. JAMA 323: 1441-1442. Link: https://bit.ly/36YvkHn

Discover a bigger Impact and Visibility of your article publication with

\section{Peertechz Publications}

\section{Highlights}

* Signatory publisher of ORCID

* Signatory Publisher of DORA (San Francisco Declaration on Research Assessment)

* Articles archived in worlds' renowned service providers such as Portico, CNKI, AGRIS, TDNet, Base (Bielefeld University Library), CrossRef, Scilit, J-Gate etc.

* Journals indexed in ICMJE, SHERPA/ROMEO, Google Scholar etc.

* OAI-PMH (Open Archives Initiative Protocol for Metadata Harvesting)

* Dedicated Editorial Board for every journa

- Accurate and rapid peer-review process

- Increased citations of published articles through promotions

* Reduced timeline for article publication

Submit your articles and experience a new surge in publication services (https://www.peertechz.com/submission).

Peertechz journals wishes everlasting success in your every endeavours.

Copyright: ( 2019 Coutaz M, et al. This is an open-access article distributed under the terms of the Creative Commons Attribution License, which permits unrestricted use distribution, and reproduction in any medium, provided the original author and source are credited.

Citation: Coutaz M, Lagrandeur J, Cecilia B, Corinne C (2020) Prognosis of frail hospitalized COVID-19 patient: Better than expected?. Arch Gerontol Geriatr Res 5(1): 012-016. DOI: http://dx.doi.org/10.17352/aggr.000018 